\title{
Crininicaminus giberti isp. nov.: Tubular trace fossil armored with crinoid stem plates from the Upper Permian Kamiyasse Formation, Northeastern Japan
}

\author{
Koji SEIKE ${ }^{I^{*}}$, Yuta SHIINO² \& Yutaro SUZUKI
}

\author{
${ }^{1}$ Atmosphere and Ocean Research Institute, University of Tokyo, 5-1-5 Kashiwanoha, Kashiwa 277-8564, Japan; \\ seike@aori.u-tokyo.ac.jp \\ ${ }^{2}$ Institute of Science and Technology, Academic Assembly, Nigata University, 8050, Ikarashi 2-no-cho, Nishi-ku, Niigata, 950- \\ 2181, Japan; y-shiino@geo.sc.niigata-u.ac.jp \\ ${ }^{3}$ Institute of Geosciences, Shizuoka University 836 Ohya, Suruga, Shizuoka, 422-8529, Japan; sysuzuk@ipc.shizuoka.ac.jp \\ * Corresponding author
}

Seike, K., Shiino, Y. \& Suzuki, Y. 2014. Crininicaminus giberti isp. nov.: Tubular trace fossil armored with crinoid stem plates from the Upper Permian Kamiyasse Formation, Northeastern Japan. [Crininicaminus giberti isp. nov.: un ichnofósil tubular de pared compuesta por placas pedunculares de crinoideo del Pérmico Superior de la Formación Kamiyasse, noreste de Japón]. Spanish Journal of Palaeontology, 29 (1), 45-50.

\begin{abstract}
The tubular trace fossil Crininicaminus giberti, a horizontal tubular fossil burrow whose wall consists of numerous crinoid stem plates, occurs in the Upper Permian Kamiyasse Formation of northeastern Japan. The trace fossil described here measures $40-70 \mathrm{~mm}$ in length and 7-20 $\mathrm{mm}$ in diameter. The outer wall of the tube is characterized by numerous skeletal fragments, with most being crinoid stem plates $(2 \mathrm{~mm}$ in diameter) and lesser fragments of brachiopods and other invertebrates. The inner wall of the tube is covered with a smooth lining devoid of crinoid skeletal elements. Because stalked crinoids mainly inhabited shallow water settings prior to the Cretaceous, it is possible that additional specimens of the ichnogenus Crininicaminus will be discovered from deposits of various ages and locations.
\end{abstract}

Keywords: Trace fossil, bioclast, crinoid, Capitanian, Permian.

\section{RESUMEN}

Se describe el icnofósil Crininicaminus giberti en el Pérmico Superior de la Formación Kamiyasse del noreste de Japón. Se trata de una madriguera horizontal y tubular cuya pared está compuesta por numerosas placas pedunculares de crinoideo, con unas dimensiones de 40-70 $\mathrm{mm}$ de longitud y 7-20 mm de diámetro. La pared externa de dicha madriguera se caracteriza por presentar gran cantidad de fragmentos esqueléticos, principalmente placas pedunculares de crinoideo $(2 \mathrm{~mm}$ de diámetro) y en menor medida fragmentos de braquiópodos y otros invertebrados. La pared interna está cubierta por un revestimiento liso carente de elementos esqueléticos. Puesto que los crinoideos pedunculados habitaban principalmente ambientes marinos someros antes del Cretácico, es posible que en el futuro se describan nuevos ejemplares del icnogénero Crininicaminus en diferentes localidades y periodos geológicos.

Palabras clave: Pista fósil, bioclastos, crinoideos, Capitaniense, Pérmico. 


\section{INTRODUCTION}

Bioclasts are utilized in tube construction and/or as camouflage materials by certain species. Typical examples are the shell-armored vertical tube produced by the marine polychaete Diopatra (Myers, 1972; Bromley, 1996), and freshwater larval caddisfly cases armored with shell and/or lithic fragments (e.g., Boucot, 1990). These shell-armored structures are preserved as trace fossils in the geological record (Kern, 1978; Ettensohn, 1981; Jarzembowski, 1995; Bromley, 1996; Ivanov \& Sukatsheva, 2002; Monaco et al., 2005; Jach et al., 2011; Zaton et al., 2012); hence, studies on trace fossils ornamented with bioclasts enable us to understand the nature of ancient animalbioclast relationships.

We have previously documented the macrofauna and stratigraphy of the Upper Permian Kamiyasse Formation in northeastern Japan, which was deposited in a shallowmarine setting (e.g., Shiino \& Suzuki, 2007; Shiino et al., 2008, 2011; Kobayashi et al., 2009). During the course of additional fieldwork, a shell-armored trace fossil was discovered within the formation. The present paper describes the morphology of this trace fossil in detail, and proposes a new ichnospecies: Crininicaminus giberti. The report of this new ichnospecies from the Permian shallowmarine deposits provides important paleoecological information on the relationships between benthic animals and skeletal fragments (bioclasts) during the Paleozoic and pre-Cretaceous Mesozoic. All specimens described and illustrated herein are housed at the University Museum, University of Tokyo (UMUT), Japan.

\section{LOCATION AND STRATIGRAPHY}

All the specimens described herein were collected from the Kamiyasse region of the Southern Kitakami Massif, northeast Japan, where a fossiliferous Middle Permian sequence is exposed (Fig. 1; Tazawa, 1973; Misaki \& Ehiro, 2004; Shiino \& Suzuki, 2007; Shiino et al., 2008, 2011; Kobayashi et al., 2009).

The Middle Permian sequence in the Kamiyasse area consists of the following three formations (in ascending order): the Hoso-o, Kamiyasse, and Kurosawa formations (Misaki \& Ehiro, 2004). Based on previous biostratigraphic studies, the formations have been assigned in ages of Upper Cisuralian to Lower Guadalupian, Middle Guadalupian, and Upper Guadalupian, respectively (e.g., Morikawa, 1960; Choi, 1973; Misaki \& Ehiro, 2004). Recent studies have revealed that the upper parts of the Hoso-o and Kamiyasse formations can be correlated with the Midian Stage (Shiino et al., 2008; Kobayashi et al., 2009; Shiino et al., 2011). Figure 2 shows lithostratigraphic columns for the five routes considered in the present study and correlations among them.

The Hoso-o Formation consists mainly of alternating beds of mudstone and sandstone/fossiliferous pavement beds in a coarsening and thickening-upward sequence. The beds of clast-supported conglomerate are lenticular in shape and occur locally. The lower part of the Kamiyasse Formation is characterized by skeletal packstone and grainstone with medium- to coarse-grained sandstone beds in the basal part. These beds are overlain by matrixsupported conglomerate bed, followed by poorly sorted fine-grained sandstone beds rest on the skeletal packstone and grainstone. The Kurosawa Formation comprises alternating beds of black mudstone and sandstone beds in a fining- and thinning-upward sequence, locally intercalated with lenticular beds of matrix-supported conglomerate.

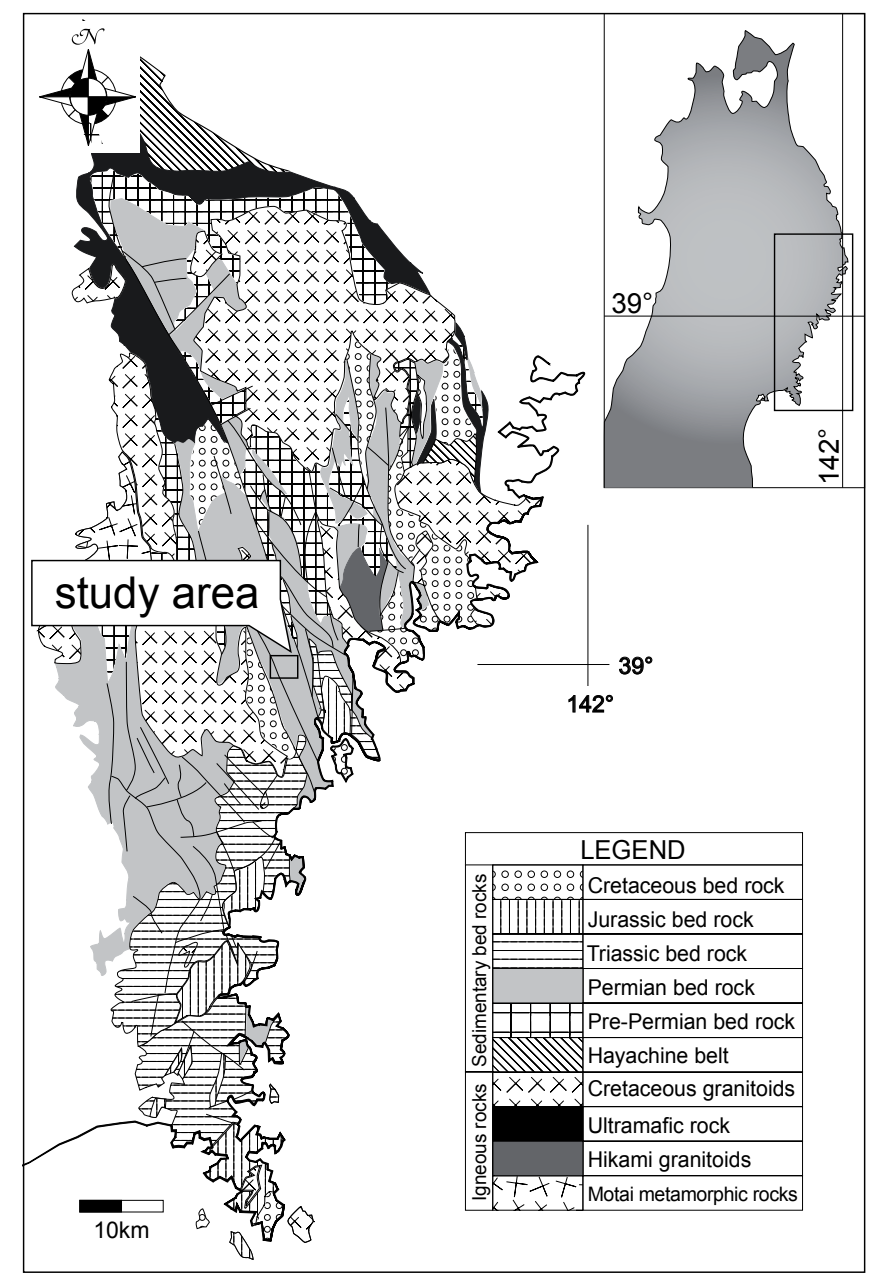

Figure 1. Geological map of the Kitakami Massif, northeastern Japan showing the location of the study area.

The upper part of the Kamiyasse Formation, which yielded the present specimens of Crininicaminus (Fig. 2), is alternating beds of fossil pavement (including numerous crinoid stem plates, brachiopods, and trilobites) and fine- 
grained sandstone. The Crininicaminus-bearing horizon consists of fine-grained sandstone.

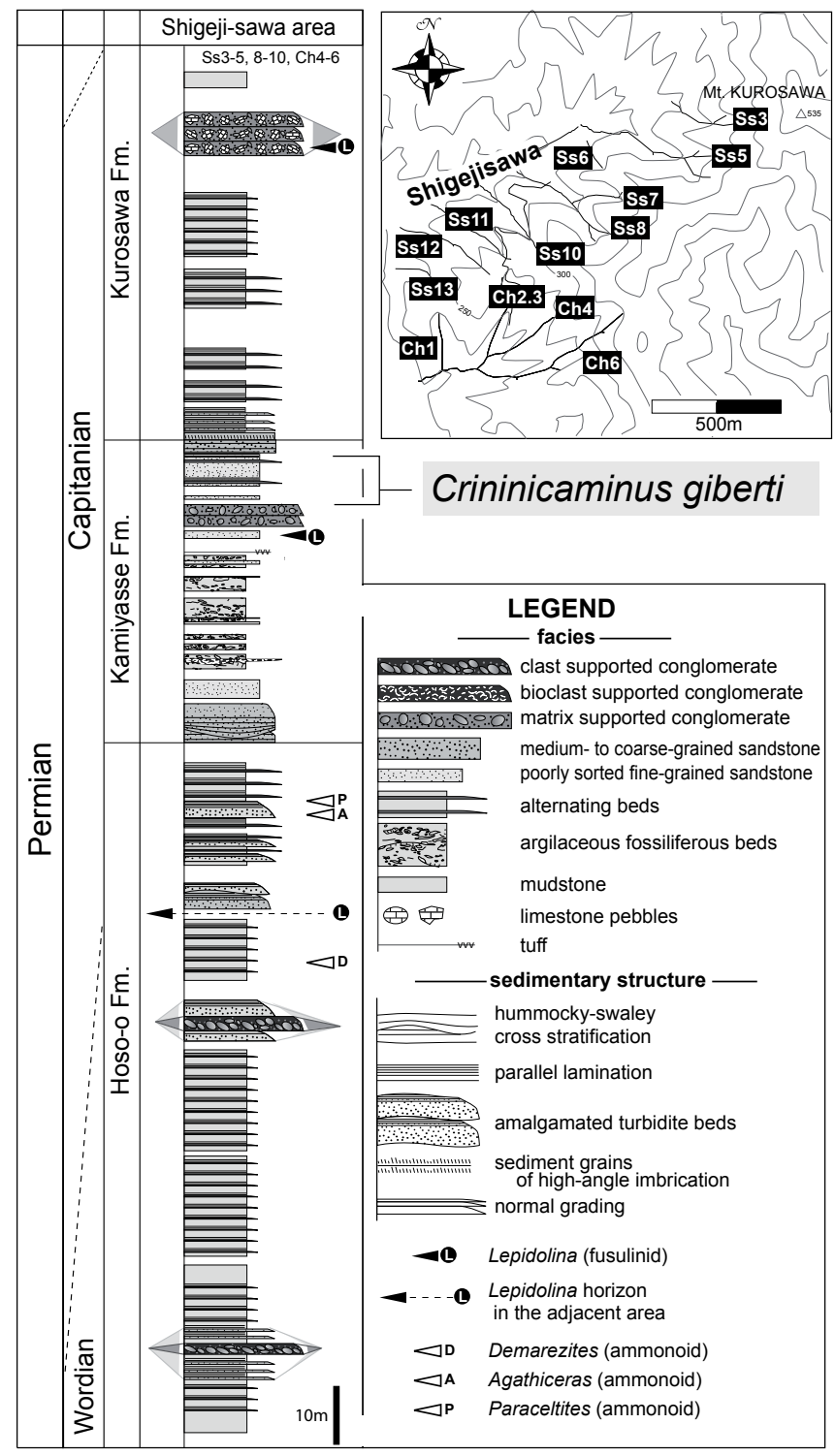

Figure 2. Generalized columnar section of the Kamiyasse area. The trace fossil Crininicaminus giberti occurs within the upper part of the Kamiyasse Formation. Modified after Shiino \& Suzuki (2007).

\section{SYSTEMATIC ICHNOLOGY}

Ichnogenus Crininicaminus Ettensohn, 1981

Ichnospecies Crininicaminus giberti isp. nov. (Fig. 3)

Derivatio nominis. In honor of Dr. Jordi Maria de Gibert.

Holotype. UMUT-PW30072 (Figs 3a-b).
Paratypes. UMUT-PW30073 (Figs 3c-d) and UMUTPW30074.

Diagnosis. A slightly tapered, unbranched cylindrical agglutinated tube composed of numerous well-sorted crinoid stem plates added to externally to the tube in a series of adjacent columns vertical to the long axis of the tube. The inner wall is covered with a smooth lining. The lumen of the tube is composed of sediment particles similar to those of surrounding strata.

Description. The tubular trace fossil described herein measures $40-70 \mathrm{~mm}$ in length 7-20 $\mathrm{mm}$ in diameter, and is preferentially oriented parallel to bedding. The bioclasts adhered to the outer wall are mainly of crinoid stem plates of $2 \mathrm{~mm}$ in diameter. Fragments of brachiopods and other invertebrates are also attached to the wall. The tube base is planar and is covered with well-sorted crinoid stem plates (Figs 3a-b). The top and sides of the tube are covered by skeletal fragments of varying type and size, showing a coarsening-centrifugal distribution (Figs 3c-d), convex shape, and thicker ornamentation than the tube base. The side edge of the tube consists of relatively large bioclasts such as brachiopod shells (Figs 3a-b).

Remarks. Tubular trace fossils ornamented with bioclasts have previously been described based on the nature of conglutinated materials and/or tube orientation (Jach et al., 2011). For example, Kern (1978) reported Diopatrichnus roederensis, a vertical shaft armored largely with the shells of bivalve molluscs. Gibert (1996) also described another ichnospecies of Diopatrichnus, D. odlingi from the Middle Jurassic of Oxfordshire (UK). Ettensohn (1981) described a horizontal tube ornamented with tabular skeletal fragments (described as a biotaxon, but ichnotaxon in fact): its type ichnospecies $C$. haneyensis is characterized by ornamentation of the outer wall with tabular crinoid stem plates. Suhr (1988) summarized the ichnogenus Lepidenteron, and divided it to four ichnospecies based on the nature of adhered material: L. lewesiensis (composed of remains of fishes), L. mantelii (composed of plant detritus), L. cancellata (composed of sand or mud grains), and $L$. variabilis (composed of various building structures). Jarzembowski (1995) distinguished among case-shaped trace fossils from fluvial deposits based on the nature of adhered material, describing Conchindusia rasnitsyni (composed of conchostracan valves), Pelindusia percealleni (composed of bivalve fragments), and Piscindusia sukachevae (composed of fish bones). Monaco et al. (2005) described the trace fossil Ereipichnus, a horizontal tube ornamented with tabular skeletal fragments (mainly orbitolinid foraminifers). Jach et al. (2011) also reported Nummipera eocenica, which is built of Discocyclina and Nummulities (larger foraminifera) tests. Hence, the trace fossil described in this study undoubtedly represents a new 

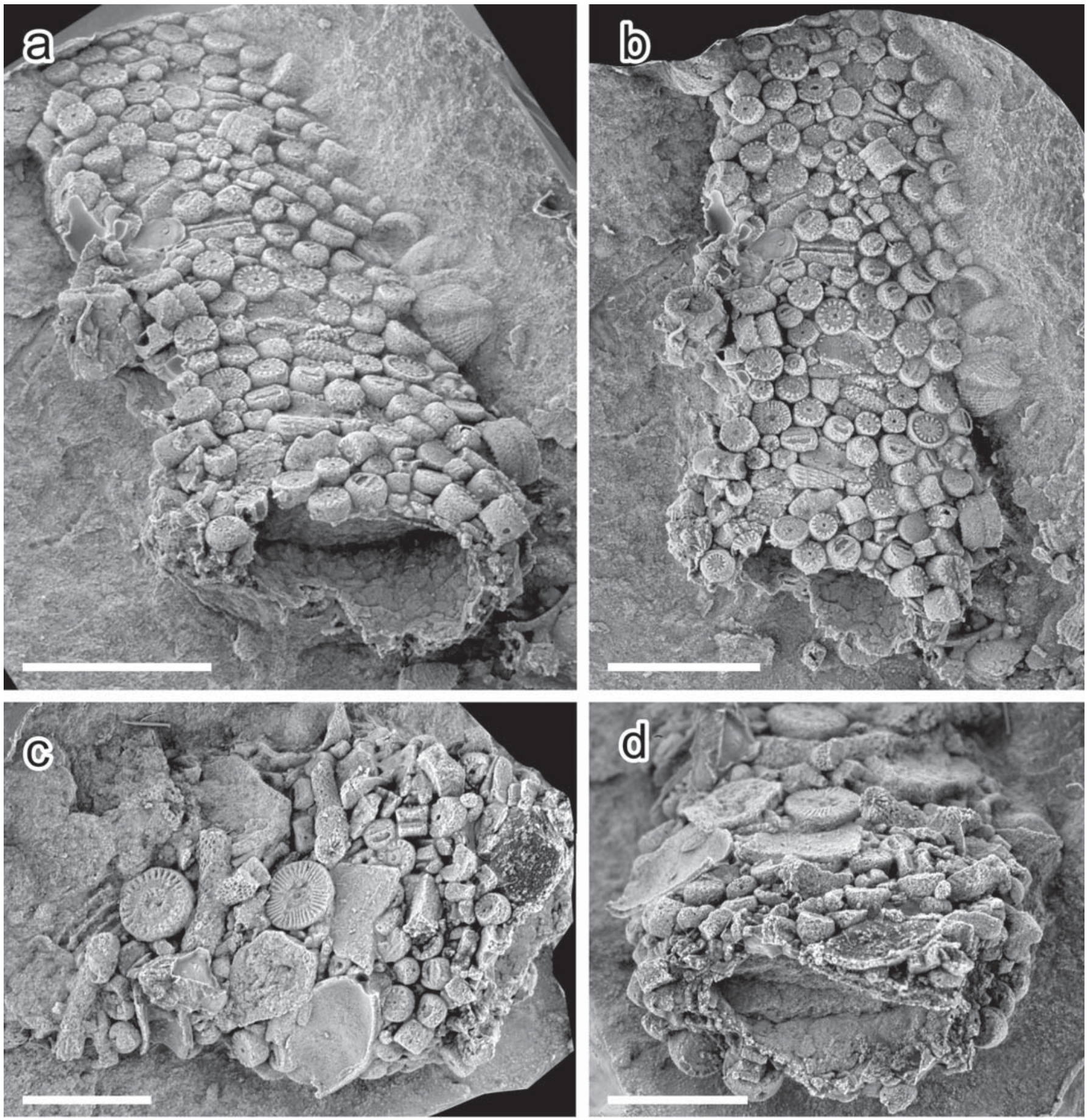

Figure 3. Referred specimens of Crininicaminus giberti isp nov. a) Oblique view of lower part (tube floor) of the trace fossil $C$. giberti (UMUT-PW30072). The outer wall is ornamented with numerous well-sorted crinoid stem plates, whereas the inner wall is covered with a smooth lining. b) Tube base of $C$. giberti (UMUT-PW30072), as viewed from below, showing ornamentation with numerous well-sorted crinoid stem plates. c) Tube top of C. giberti (UMUT-PW30073), as viewed from above. Note the difference in surface ornamentation between the lower (tube base: Figs 3a-b) and upper (tube top: Figs 3c-d) surfaces. The top (roof) of the tube is covered by various types of relatively large skeletal fragments. d) Oblique view of the upper part (tube top) of the trace fossil C. giberti (UMUT-PW30073). Scale bar $=10 \mathrm{~mm}$.

ichnospecies of Crininicaminus, as the tube is horizontal and ornamented with numerous tabular crinoid stem plates. The new ichnospecies $C$. giberti is distinguishable from $C$. haneyensis by mode of crinoid' stem plate arrangement (vertical to the long axis of the tube).
Geographic and stratigraphical distribution. The type locality consists of a poorly sorted fine-grained sandstone bed within the upper part of the Kamiyasse Formation in the mountainside along the armlet of Shigejizawa creek (route Ss 3 in Fig. 2). The bed has been dated 
to the Upper Midian of the Tethyan stage and to the Middle-Upper Capitanian of the Standard stage (Shiino et al., 2008, 2011; Kobayashi et al., 2009).

Discussion. Crininicaminus giberti described herein occurs within fine-grained sandstone layers, thereby demonstrating that the tubular structure is biogenic in origin and autochthonous (i.e., trace fossils are rarely transported from the site of origin).

Stalked crinoids are today restricted to the deep sea, but during the Paleozoic and pre-Cretaceous Mesozoic (i.e., until the Mesozoic Marine Revolution) were important constituents of shallow-water bottom communities (e.g., Vermeij, 1977; Bottjer \& Jablonski, 1988; Oji, 1996). Consequently, crinoid stem plates would have been abundant as bioclasts on the seafloor at this time, available for use in tube construction and/or as camouflage material. In fact, the type species of Crininicaminus, C. haneyensis is also described from the Carboniferous shaly limestone in east-central Kentucky, USA. Hence, it is possible that additional specimens of Crininicaminus will be discovered in future studies of shallow-marine deposits of various ages and locations.

\section{ACKNOWLEDGMENTS}

This paper is dedicated to the memory of our late colleague and friend, Dr. Jordi Maria de Gibert. Jordi always provided lively and fruitful ichnological discussion in the field and elsewhere. He provided generous support to KS throughout his professional career, and he is truly missed. We thank A. Uchman, N.J. Minter, A. Giannetti and P. Monaco for discussions on tube armored trace fossils, and Y. Takaizumi for providing additional specimens of Crininicaminus giberti. This work was financially supported by a Research Fellowship awarded by the Japan Society for the Promotion of Science.

\section{REFERENCES}

Bottjer, D.J. \& Jablonski, D. 1988. Paleoenvironmental patterns in the evolution of post-Paleozoic benthic marine invertebrates. Palaios, 3, 540-560.

Boucot, A.J. 1990. Evolutionary Paleobiology of Behavior and Coevolution. Elsevier, Amsterdam.

Bromley, R.G. 1996. Trace Fossils-Biology, Taphonomy and Applications. Chapman \& Hall, London.

Choi, D.R. 1973. Permian fusulinids from the Setamai-Yahagi district, Southern Kitakami Mountains, N. E. Japan. Journal of the Faculty of Science Hokkaido University Series 4, 16, 1-132.
Ettensohn, F.R. 1981. Crininicaminus haneyensis, a new agglutinated worm tube from the Chesterian of east-central Kentucky. Journal of Paleontology, 55, 479-482.

Gibert, J.M. de 1996. Diopatrichnus odlingi n. isp. (annelid tube) and associated ichnofabrics in the White Limestone (M. Jurassic) of Oxfordshire: sedimentological and palaeoecological significance. Proceedings of the Geologists ‘ Association, 107, 189-198.

Inavov, V.D. \& Sukatsheva, I.D. 2002. Order Trichoptera Kirby, 1813. The caddisflies. In: History of Insects (eds Rasnitsyn, A.P. \& Quicke, D.L.J.). Kluwer Academic Publishers, Dordrecht, 199-220.

Jach, R., Machaniec, E. \& Uchman, A. 2011. The trace fossil Nummipera eocenica from the Tatra Mountains, Poland: morphology and palaeoenvironmental implications. Lethaia, 45, 342-355.

Jarzembowski, E.A. 1995. Fossil caddsiflies (Insecta: Trichoptera) from the Early Cretaceous of southern England. Cretaceous Research, 16, 695-703.

Kern, J.P. 1978. Paleoenvironment of new trace fossils from the Eocene Mission Valley Formation, California. Journal of Paleontology, 52, 186-194.

Kobayashi, F., Shiino, Y. \& Suzuki, Y. 2009. Middle Permian (Midian) foraminifers of the Kamiyasse Formation in the Southern Kitakami Terrane, NE Japan. Paleontological Research, 13, 79-99.

Misaki, A. \& Ehiro, M. 2004. Stratigraphy and geologic age of the Middle Permian in the Kamiyasse-Imo District, southern Kitakami Massif, northeast Japan. Journal of the Geological Society of Japan, 110, 129-145.

Monaco, P., Giannetti, A., Caracuel, J.E. \& Yébenes, A. 2005. Lower Cretaceous (Albian) shell-armoured and associated echinoid trace fossils from the Sácaras Formation, Serra Gelada area, southeast Spain. Lethaia, 38, 333-344.

Morikawa, R. 1960. Fusulinids from the Iwaizaki Limestone. Science Report of the Saitama University Series B, 3, 273-299.

Myers, A.C. 1972. Tube-worm-sediment relationships of Diopatra cuprea (Polychaeta: Onuphidae). Marine Biology, 17, 350-356.

Oji, T. 1996. Is predation intensity reduced with increasing depth? Evidence from the west Atlantic stalked crinoid Endoxocrinus parrae (Gervais) and implications for the Mesozoic marine revolution. Paleobiology, 22, 339-351.

Shiino, Y. \& Suzuki, Y. 2007. Articulatory and musculatory systems in a Permian concavo-convex brachiopod Waagenoconcha imperfecta Predergast, 1935 (Productida, Brachiopoda). Paleontological Research, 11, 265-275.

Shiino, Y., Suzuki, Y. \& Kobayashi, F. 2008. Middle Permian fusulines from the Hoso-o Formation in Kamiyasse area, southern Kitakami Mountains, Northeast Japan: Their biostratigraphic implications. Journal of the Geological Society of Japan, 114, 200-205.

Shiino, Y., Suzuki, Y. \& Kobayashi, F. 2011. Sedimentary history with biotic reaction in the Middle Permian shelly sequence of the Southern Kitakami Massif, Japan. Island Arc, 20, 203-220. 
Suhr, P. 1988: Taxonomie und ichnologie fossiler Wohnröhren terebelloider Würmer. Freiberger Forschungshefte, C419, 81-87.

Tazawa, J. 1973. Geology of the Kamiyasse area, Southern Kitakami Mountains. Journal of the Geological Society of Japan, 79, 677-686.
Vermeij, G.J. 1977. The Mesozoic marine revolution: evidence from snails, predators and grazers. Paleobiology, $3,245-258$.

Zaton, M., Kano, Y., Wilson, M.A. \& Filipiak, P. 2012. Unusual tubular fossils associated with microbial crusts from the Middle Jurassic of Poland: agglutinated polychaete worm tubes? Palaios, 27, 550-559. 